\title{
The Influence of Geotextiles Stabilizing the Soil on Vegetation of Post-Excavation Slopes and Drainage Ditches
}

\author{
Katarzyna Kobiela-Mendrek', Anna Salachna ${ }^{1 *}$, Damian Chmura', \\ Henryk Klama', Jan Broda' \\ 1 Faculty of Materials, Civil and Environmental Engineering, University of Bielsko-Biala, ul. Willowa 2, 43-309 \\ Bielsko-Biała, Poland \\ * Corresponding author's e-mail: asalachna@ath.bielsko.pl
}

\begin{abstract}
The paper presents preliminary results of the studies concerning influence of geotextiles stabilizing the soil on vegetation of post-excavation slopes and drainage ditches. Analyzed anthropogenic habitats are situated in Międzyrzecze and Nieboczowy (Silesian Province, Southhern Poland). They have been previously subjected to reclamation treatment, consisting in installation of wool and synthetic geotextiles in the ground. The studies on plant community were conducted according to commonly applied Braun-Blanquet approach. Recorded phytocenosis were classified into Molinio-Arrhenatheretea R. Tx.1937 and Stellarietea mediae R. Tx., Lohm. et Prsg. 1950 class. For comparison of plant patches growing on two variants of geotextiles Hierarchical Cluster Analysis was used. Moreover, the number of species (S), Shannon-Wiener index (H), evenness index (J) and average heights of herbal layer were calculated. It has been shown, that the type of geotextiles has a slight influence on the variability of investigated plant patches. However, relatively high differences in total coverage and mean height of herbal layer between plots protected and unprotected were observed. It shows that the geotextiles support the process of natural ecological succession on habitats with high inclination, mainly through water retention and reduction of erosion.
\end{abstract}

Keywords: ecological succession, synanthropic communities, biodiversity indicators, recultivation, geotextiles

\section{INTRODUCTION}

The natural, ecological succession on the various anthropogenic habitats is a well-known and documented phenomenon [Borgegard 1990; Badora et al. 2004; Kompała 1997; Rostański 2006; Rehounkova 2007; Woźniak 2010]. The role of this process in the reclamation of post-industrial areas is often emphasized [Krzaklewski 1999, Patrzałek 2000]. Spontaneous vegetation, among other advantages, increases the effectiveness of various recultivation treatments, such as the use of geotextiles to stabilize the steep post-excavation slopes and drainage ditches. The materials used for this purpose are derived from natural and man-made fibers. They differ in the properties including, for example, resistance to biodegradation. In the case of geotex- tiles made of wool fibers, a significant reduction of their mechanical parameters and structural degradation is observed already a year after the installation, while synthetic fibers do not show similar changes [Broda et al. 2017a,b]. Decomposition of wool keratin by microorganism releases mainly nitrogen into the soil [Broda et al. 2017c; Vončina 2013; Zheljazkov 2009], which supports plant development.

There is an enormous body of literature describing the natural ecological succession but relatively few publications concern the possibility of modelling this process. The main goal of these study was to answer the question: what is the influence of the type of geotextile (wool and synthetic) used to stabilize the soil on the variability of plant communities (structure, species richness and species composition)? 


\section{MATERIAL AND METHODS}

\section{Localization and characteristic of study plots}

The present study was performed on different anthropogenic habitats located in Southern Poland, in Silesian Province. The first stand is situated on the border between two mesoregions: the Upper Vistula River Valley and the Silesian Foothils [Kondracki 1994]. In terms of administrative division, it belongs to the rural commune Jasienica near Bielsko-Biała, on the territory of a newly formed low emission investment zone in Międzyrzecze (Figure 1). Here, the investigations were carried out on the steep bed slope of a deep drainage ditch.

The analyzed place has a western and northwestern exposure, inclination of 1 in 1.5 (Table 1) and the length of 4 to $6 \mathrm{~m}$. The other stand is lo- cated in the area of a disused gravel pit in Nieboczowy and administratively belongs to the rural commune Lubomia near Wodzisław Śląski (Figure 1). Geografically it is mesoregion of the Raciborska Basin [Kondracki 1994]. In this site, the study was conducted on the steep slopes of exploitation hollow, formed as a consequence of gravel extraction. The slope has an eastern exposure, its inclination varies from 1 in 0.8 to 1 in 1.8 (Table 1) and length varies from 4 to 6 meters.

\section{Geotextiles characteristic}

Two variants of geotextiles were used to protect study plots. Both of them were produced by using the Kemafil technique [Helbig et al. 2006]. One variant had a core made of stripes of woollen needle-punched nonwoven fabric. The other was made out of stitch-bonded nonwoven fabric,

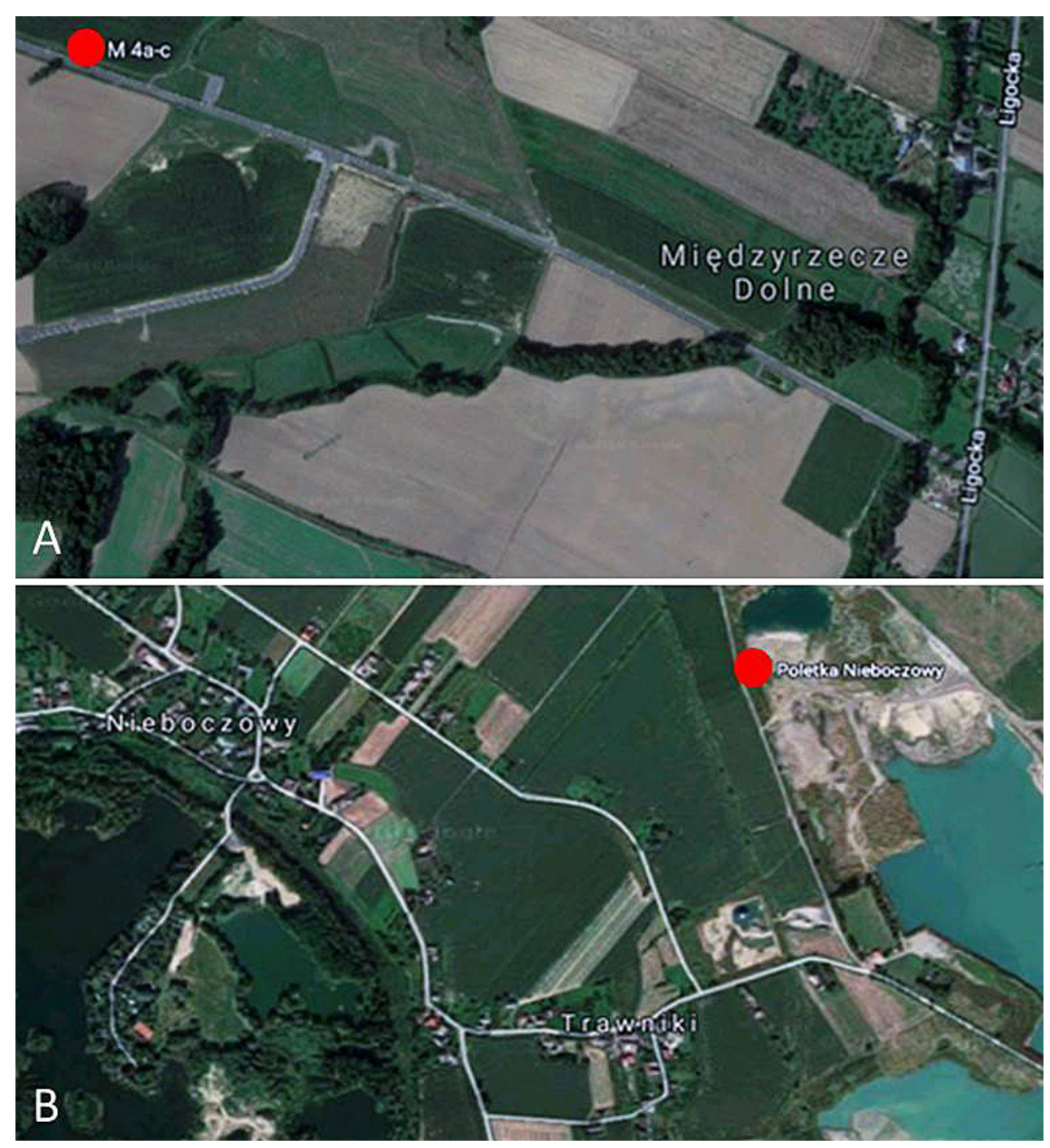

Figure 1. Location of study plots: A. Międzyrzecze, B. Nieboczowy (study plots are marked with red circles) [https://www.google.pl/maps, modified] 
Table 1. The parameters of study plots

\begin{tabular}{|c|c|c|c|}
\hline \multirow{2}{*}{ Stand } & \multicolumn{3}{|c|}{ Plots } \\
\cline { 2 - 4 } & geographical coordinates & exposure & inclination \\
\hline Międzyrzecze & $49^{\circ} 51^{\prime} 55.3^{\prime} \mathrm{N}, 18^{\circ} 55^{\prime} 51^{\prime \prime} \mathrm{E}$ & $\mathrm{W}, \mathrm{N}-\mathrm{W}$ & $1: 1.5$ \\
\hline Nieboczowy & $50^{\circ} 02^{\prime} 36.5^{\prime} \mathrm{N}, 18^{\circ} 16^{\prime} 21.2^{\prime} \mathrm{E}$ & $\mathrm{E}$ & $1: 0.8 ; 1: 1.8$ \\
\hline
\end{tabular}

for which the post-consumer textiles were shredded and carded to obtain fibre blend [Broda et al. 2017 a]. Fibre blend comprises over $50 \%$ of synthetic fibres as well as some wool, cotton and viscose. The composition of the stitch-bonded nonwoven fabric in particular segments might vary slightly. They were anchored using steel U-shape pins that were made by bonding ribbed bars with the length of about $1 \mathrm{~m}$ and diameter of 6 or $8 \mathrm{~mm}$.

\section{Vegetation analysis}

The vegetation sampling of plant community was made in the vegetation season 2017. A total of 12 phytosociological relevès were taken (Table 2), according to the commonly applied Braun-Blanquet approach. Additionally, the height of herb layer in three randomly selected points on each plot was measured using a measuring tape. For comparison of species composition and the cover of plants growing on the plots protecting by different variants of geotextilles (wool and synthetics) Hierarchical Cluster Analysis (Ward's method, Manhatan (city-block) measure) was done. Moreover, the number of species (S), Shannon-Wiener index $(\mathrm{H})$, evenness index $(\mathrm{J})$ and average heights of herb layer were calculated. The phytosociological table with cover of all recorded species on the plots with two types of geotextiles were given. Nomenclature follows Mirek et al. [2002] and Matuszkiewicz [2001]. The numerical analysis was made in project $\mathrm{R}$ software [R Core Team 2016].

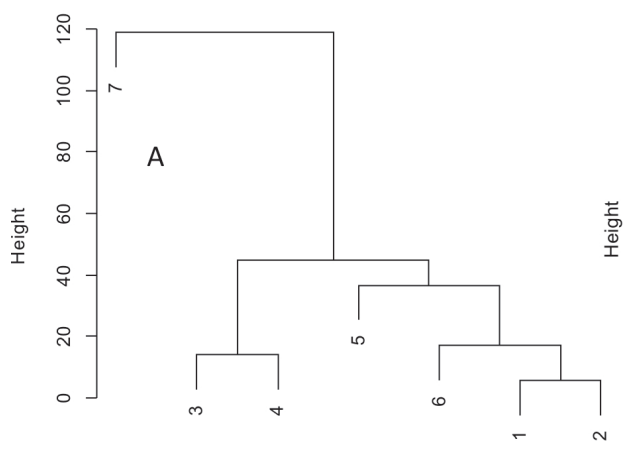

\section{RESULTS AND DISCUSSION}

The analysed phytocenoses represent seminatural and ruderal plant community. Their unequivocal classification was possible only to higher rank of syntaxons (class and alliance). The first community (in Międzyrzecze), on the basic characteristic species according to Matuszkiewicz [2001], belongs to Molinio-Arrhenatheretea class and in terms of species composition, they show some similarity to phytocenosis Agropyro-Rumicion crispi. The second community (in Nieboczowy) is classified into Sisymbrion officinalis from Stellarietea mediae class (Table 2). The species occurring in this phytocenosis (e.g. Artemisia vulgaris, Cirsium arvense, Daucus carota, Lactuca serriola, Solidago canadensis, Tussilago farfara) are recognized as the species typical for the first stage of the spontaneous ecological succession [Rostański 2006].

The Hierarchical Cluster Analysis results indicated low differentiation in the vegetation growing on the plots stabilized by using of two kinds of geotextiles. In both investigated cases, patches on ,wool” and „blend” substrates, are not separated groups on the dendrograms. The value of city block distance between them varies from 7 to 44 in Międzyrzecze and from 15 to 57 in Nieboczowy (Figure 2). For these patches, slight differences in mean value of Shannon-Wiener diversity index $(\mathrm{H})$ and evennes index $(\mathrm{J})$ were noted (Figure 4).

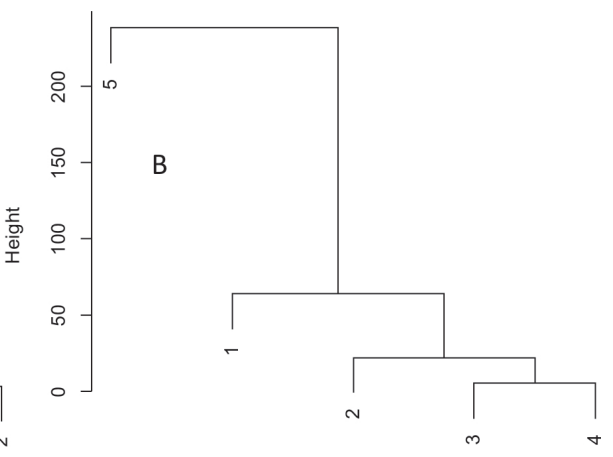

Figure 2. Dendrogram of similarity of the studied vegetation patches on the basis Manhattan distance according to Ward method: A. Międzyrzecze, B. Nieboczowy (the numbers on the dendrogram correspond to the relevès numbers listed in Table 2) 
Table 2. The phytosociological table of investigated plant communities

\begin{tabular}{|c|c|c|c|c|c|c|c|}
\hline \multirow{5}{*}{ Species } & \multicolumn{7}{|c|}{ Międzyrzecze } \\
\hline & \multicolumn{7}{|c|}{ number of relevè } \\
\hline & 1 & 2 & 3 & 4 & 5 & 6 & 7 \\
\hline & \multicolumn{7}{|c|}{ cover of herbal layer $(\%)$} \\
\hline & 75 & 70 & 85 & 85 & 70 & 75 & 50 \\
\hline \multicolumn{8}{|c|}{ Ch.Cl. Molinio-Arrhenatheretea + Ch.O. Arrhenatheretalia } \\
\hline Dactylis glomerata & . & . & 1 & . & + & + & . \\
\hline Festuca rubra & 1 & . & . & + & . & . & . \\
\hline Holcus lanatus & 1 & 1 & 1 & + & 1 & + & . \\
\hline Lotus corniculatus & . & . & . & . & . & . & + \\
\hline Poa pratensis & . & 1 & . & 1 & . & . & 1 \\
\hline Rumex acetosa & . & . & . & . & . & . & + \\
\hline Taraxacum officinale & . & . & + & . & + & . & . \\
\hline \multicolumn{8}{|l|}{ Ch. All. Agropyro-Rumicion crispi } \\
\hline Agropyron repens & 3 & 3 & 3 & 3 & 3 & 2 & . \\
\hline Agrostis stolonifera & . & . & . & 1 & + & 1 & . \\
\hline Lysimachia nummularia & . & . & . & + & + & . & . \\
\hline Ranunculus repens & . & + & + & + & . & . & . \\
\hline Rumex crispus & . & 1 & . & . & 1 & . & . \\
\hline \multicolumn{8}{|l|}{ Ch. Cl. Artemisetea } \\
\hline Cirsium arvense & 1 & + & 1 & + & . & . & . \\
\hline Urtica dioica & . & 1 & & 2 & 1 & 1 & . \\
\hline \multicolumn{8}{|l|}{ Other species } \\
\hline Alnus glutinosa & . & . & . & . & . & . & + \\
\hline Carex nigra & . & . & . & . & . & . & 1 \\
\hline Carex ovalis & + & . & . & . & . & . & 1 \\
\hline Carex rostrata & + & . & . & . & . & . & . \\
\hline Equisetum arvense & + & + & + & . & + & . & . \\
\hline Festuca ovina & . & . & + & . & . & . & . \\
\hline Galium aparine & . & + & . & . & . & . & . \\
\hline Humulus lupulus & . & . & + & + & + & . & . \\
\hline Hypericum maculatum & . & . & + & . & . & . & 1 \\
\hline Impatiens parviflora & . & . & . & . & + & + & . \\
\hline Juncus conglomeratus & . & . & . & . & . & . & + \\
\hline Lolium perenne & . & . & + & . & . & . & . \\
\hline Luzula campestris & . & . & . & . & . & . & 1 \\
\hline Lythrum salicaria & . & . & + & . & . & . & . \\
\hline Oxalis fontana & . & . & . & . & . & . & + \\
\hline Quercus robur & . & + & . & . & + & . & . \\
\hline Rubus caesius & 1 & . & + & . & 1 & 1 & . \\
\hline Scrophularia nodosa & . & . & . & . & . & . & + \\
\hline Tanacetum vulgare & . & . & . & . & . & . & 1 \\
\hline Tussilago farfara & . & + & 1 & . & . & . & . \\
\hline Vicia hirsuta & . & . & + & . & . & . & . \\
\hline Vicia tetrasperma & . & + & + & . & . & . & . \\
\hline
\end{tabular}


Table 2 cont.

\begin{tabular}{|c|c|c|c|c|c|}
\hline \multirow{5}{*}{ Species } & \multicolumn{5}{|c|}{ Nieboczowy } \\
\hline & \multicolumn{5}{|c|}{ number of relevè } \\
\hline & 1 & 2 & 3 & 4 & 5 \\
\hline & \multicolumn{5}{|c|}{ cover of herbal layer $(\%)$} \\
\hline & 85 & 75 & 70 & 75 & 55 \\
\hline \multicolumn{6}{|c|}{ Ch.Cl. Stellarietea mediae +Ch. All. Sisymbrion } \\
\hline Lactuca serriola & 2 & 1 & 3 & 2 & . \\
\hline Lapsana communis & + & + & + & + & . \\
\hline Matricaria maritima ssp.inodora & . & + & + & . & . \\
\hline Sinapis arvensis & 2 & 3 & 2 & 2 & . \\
\hline Thlaspi arvense & . & + & . & + & 1 \\
\hline \multicolumn{6}{|l|}{ Ch. Cl. Artemisetea } \\
\hline Artemisia vulgaris & . & + & + & . & 1 \\
\hline Cirsium arvense & 1 & 2 & 1 & 1 & . \\
\hline Rumex obtusifolius & + & + & + & + & . \\
\hline \multicolumn{6}{|c|}{ Ch.Cl. Molinio.Arrhenatheretea + Ch.O. Arrhenatheretalia } \\
\hline Crepis biennis & + & . & . & . & . \\
\hline Daucus carota & + & . & . & + & . \\
\hline Lotus corniculatus & . & . & + & . & 1 \\
\hline Prunella vulgaris & + & + & . & . & . \\
\hline \multicolumn{6}{|l|}{ Other species } \\
\hline Bidens frondosa & . & + & . & . & 1 \\
\hline Calystegia sepium & + & + & + & + & + \\
\hline Capsella bursa.pastoris & + & + & . & . & . \\
\hline Chamaenerion angustifolium & . & + &. & + & 1 \\
\hline Galium mollugo & . & + & . & . & 1 \\
\hline Glechoma hederacea & + & . & + & . & . \\
\hline Lolium multiflorum & . & 1 & . & 1 & . \\
\hline Lythrum salicaria & + & . & + & + & . \\
\hline Mentha arvensis & + & . & + & . & . \\
\hline Oxalis fontana & + & + & + & + & . \\
\hline Phalaris arundinacea & + & . & . & . & . \\
\hline Plantago major & . & + & . & . & 1 \\
\hline Scrophularia nodosa & + & . & . & + & . \\
\hline Solidago canadensis & . & 1 & . & 1 & 1 \\
\hline Symphytum officinale & + & 1 & 1 & 1 & . \\
\hline Trifolium pratense & . & . & . & . & 1 \\
\hline Tussilago farfara & 3 & 1 & 1 & . & 3 \\
\hline
\end{tabular}

Significantly higher differences in species composition and coverage of individual species were found between the plant patches growing on the protected and unprotected plots. In these cases of city-block distance has value 120 and 240 (Figure 2). Moreover, mean value of height and total coverage of herbal layer of stabilized plots are much higher than the control plot (Table 2, Figure 3).
The ambiguous results regarding the mean value of species richness were obtained. In Nieboczowy, the plots with blend geotextiles and wool geotextiles have similar mean number of species, which are much higher than in the control plot. Contrary to them, in Międzyrzecze, blend plots characterized higher mean species richness than wool, but in both cases its value is lower than in control (Figure 4). 


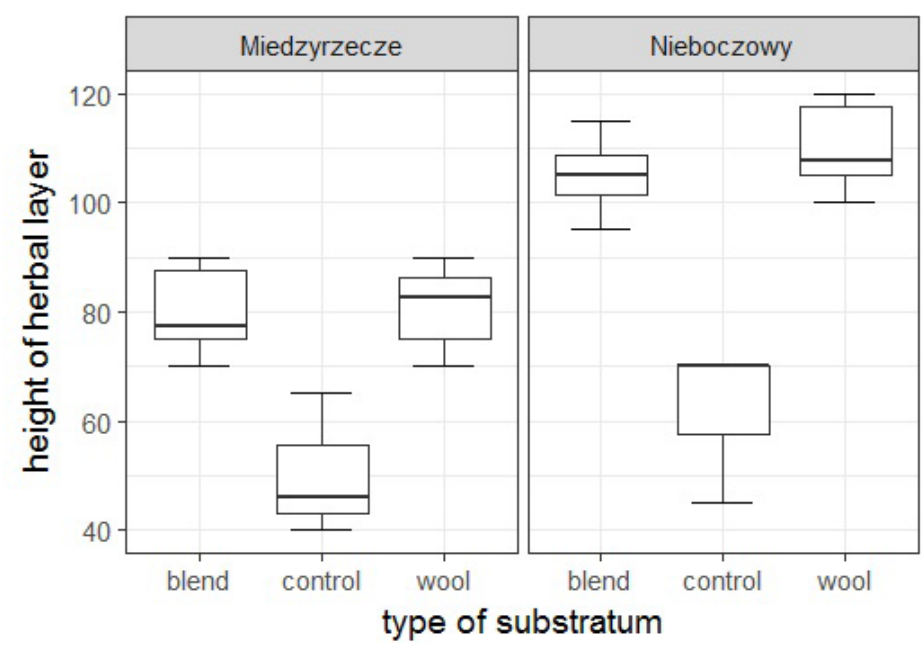

Figure 3. Average heights of herbal layer of vegetation patches on plots stabilized by different variants of geotextiles
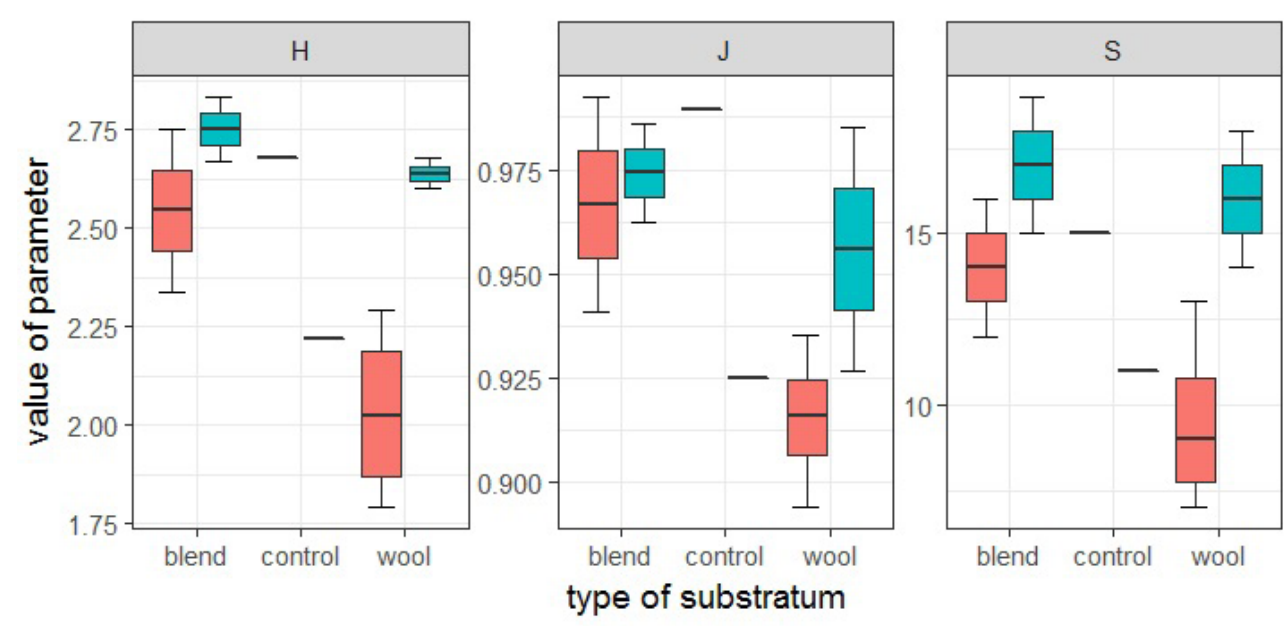

site 官 Miedzyrzecze 宁 Nieboczowy

Figure 4. The Shannon-Wiener diversity index $(\mathrm{H})$, evenness index $(\mathrm{J})$ and species richness $(\mathrm{S})$ of vegetation patches on the plots with different variants of geotextiles

The species diversity indicators applied in our study: the Shannon-Wiener diversity index and the evenness index are considered to be very sensitive even for small changes in the structure of plant community and can be used for analysis as well as to compare different phytocenosis [Kwiatkowska and Symonides 1985]. Woźniak [2010] proves that the value of these indices on the anthropogenic habitats such as coal-mine heaps depends from many factors: humidity, exposure, as well as the age of heaps.

\section{CONCLUSIONS}

1. The paper presents a preliminary research concerning influence of wool and synthetic geotextiles on the structure plant communities.
2. The obtained results confirm the previous observations of other authors [Broda et al. 2017] that the application of geotextiles (regardless of their type) supports the process of natural ecological succession on habitats with high inclination, mainly through water retention and reduction of erosion. It facilitates the occupation these places by plants and creates favourable conditions for their growth, which is manifested in higher coverage and height of herbal layer.

3. There is no significant impact of geotextile type on the species composition but only on biodiversity indices.

4. Due to the dynamics of the analyzed communities, for the complete knowledge of impact the materials used for stabilization soil on spontaneous vegetation, permanent monitoring of investigated habitats is necessary. 


\section{REFERENCES}

1. Badora K., Hebda G., Nowak A., Nowak S. 2004. Bio- and geodiversity of upper carst limestone excavation in the Opole city.. in: Kuniewski E. (editor.), Researches of the Opole Scientific Society. III Faculty. Natural Sciences, Opole, s. 3569. (in Polish)

2. Borgegard S. O. 1990. Vegetation development in abandoned gravel pits: effects of surrounding vegetation, substrate and regionality. J. Veg. Sci. 1: 675682 .

3. Broda J., Gawłowski A., Przybyło S., Biniaś D., Rom M., Grzybowska-Pietras J., Laszczak R. 2017. Innovative wool geotextiles designed for erosion protection, Journal of Industrial Textiles, DOI: $10.1177 / 1528083717695837$ (on-line).c

4. Broda J., Gawłowski A., Laszczak R., Mitka A., Przybyło S., Grzybowska-Pietras J., Rom M. 2017. Application of innovative meandrically arranged geotextiles for the protection of drainage ditches in the clay ground. Geotextiles and Geomembranes 45. 45-53.b

5. Broda J., Grzybowska-Pietras J., Gawłowski A., Rom M., Przybyło S., Laszczak R. 2017. Application of wool geotextiles for the protection of steep slopes. Proc. of 3rd International Conference on Natural Fibers: Advanced Materials for a Greener World. Braga. Portugal. 200. 112-119.a

6. Helbig R., Arnold R., Erth H., Roess T., Hevert W., Lischkowitz H. 2006. New technologies for manufacturing extra coarse rope-like biodegradable geotextiles. Technische Textilien. 49(4). E185-E187. 244-247.

7. Kompała A. 1997. Spontaneous processes of succession on the areas after exploitation of backfilling sand observing in the Katowice voivodship. Przegl. Przyr. 8 (12): 163168. (in Polish)

8. Kondracki J. 1994. Geography of Poland, Physical-geographic mesoregions. Warsaw, PWN. (in Polish)

9. Krzaklewski W. 1999. Spontaneous vegetation as an index of biotopic conditions and a basis for heaps forrestation on the illustration of Adamów Brown Coal Mine in: Krzaklewski W. (editor) Opencast minig-environmenet-reclamation with particular reference to Brown Coal Mine Bełchatów. part II. University of Agriculture in Krakow. (in Polish)

10. Kwiatkowska A.J., Symonides E. 1985. Statistical analysis of phytocoenose homogeneity. I. Distribution of the total species diversity and evenness indices as a homogeneity measure. Acta Societatis Botanicorum Botanicorum Poloniae 54(4):449-463.

11. Matuszkiewicz W. 2005. Guidebook to plant communities of Poland. PWN. Warsaw. (in Polish)

12. Mirek Z., Piękoś-Mirkowa H., Zając A. \& Zając M. 2002. Flowering plants and pteridophytes in Poland. A checklist. Biodiversity of Poland 1.

13. Patrzałek A. 2000. The spontaneously settling vegetation involvement in the sown grasses plant communities formation on the mine spoil. Fragmenta Floristica et Geobotanica Polonica 7: 215227. (in Polish)

14. R Core Team 2016. R. A language and environment for statistical computing. R Foundation for Statistical Computing, Vienna, Austria. URL http:// www.R-project.org/.

15. Řehounková K. 2007. Variability of spontaneous vegetation succession in disused gravel-sand pits: importance of environmental factors and surrounding vegetation. PhD. Thesis. University of South Bohemia, České Budějovice, Czech Republic, s. 1100.

16. Rostański A. 2006. Spontaneous plant cover on colliery spoil heaps in Upper Silesia (Southern Polanad). University of Silesia. 2410. Katowice. (in Polish)

17. Vončina A., Mihelič R. 2013. Sheep wool and leather waste as fertilizers in organic production of asparagus (Asparagus officinalis L.), Acta Agriculturae Slovenica, 101 - 2, 191- 200, DOI: 10.2478/ acas-2013-0015.

18. Woźniak G. 2010. Diversity of vegetation on coalmine heaps of the Upper Silesia (Poland). Szafer Institute of Botany, Polish Academy of Sciences, Krakow. p. 320. (in Polish).

19. Zheljazkov V.D., Stratton G.W., Pincock J., Butler S., Jeliazkova E.A., Nedkov N.K., Gerard P.D. 2009, Wool-waste as organic nutrient source for containergrown plants. Waste Management. 29: 2160-2164. 